\title{
Experimental Study of Engineered Cement Plug to Effectively Cure Losses While Drilling in Iranian 0il/Gas Well
}

\author{
Majid Sajjadian, Ehsan Esmaeilpour Motlagh, Ali Akbar Daya* \\ Department of Mining Engineering, University of Sistan and Baluchestan, Zahedan, Iran \\ Email: *aliakbardaya@eng.usb.ac.ir
}

Received 30 October 2015; accepted 31 January 2016; published 3 February 2016

Copyright (C) 2016 by authors and Scientific Research Publishing Inc.

This work is licensed under the Creative Commons Attribution International License (CC BY). http://creativecommons.org/licenses/by/4.0/

(c) (i) Open Access

\section{Abstract}

Mud losses are one of the most severe problems encountered in drilling. This is commonly known as lost circulation. It can occur in naturally fractured formations and also can be induced in formations through drilling. Mud losses while drilling leading to cost overruns and HSE concerns, primary cement job failure due to not getting the cement up to the desired height resulting in subsequent sustained casing pressure and corrosion, not able to perform work over activity on certain wells due to losses. The objective of this paper is to explain extreme lost circulation problem and introduce cement plug formulation to cure or mitigate this problem. In addition, the cement plug has certain compressive strength that this is proper for use to control lost circulation in field. And finally, the application of a cement plug is described in one well of the Gas Field (National Iranian Oil Company).

\section{Keywords}

Drilling, Lost Circulation, Cement Plug, Compressive Strength

\section{Introduction}

During drilling operation, lost circulation is an undesirable situation. Lost circulation is defined as partial or total loss of circulation mud [1]. Maybe the most difficult situation is fractured formations where the operator may face total loss. China started to study some critical lost circulation materials and only one single material is used during lost circulation. People paid more attention to standardization of lost circulation materials and in order to improve the efficiency of plugging compound lost circulation materials were used. The most important results

\footnotetext{
${ }^{*}$ Corresponding author.
}

How to cite this paper: Sajjadian, M., Motlagh, E.E. and Daya, A.A. (2016) Experimental Study of Engineered Cement Plug to Effectively Cure Losses While Drilling in Iranian Oil/Gas Well. International Journal of Geosciences, 7, 115-119. 
are the polymer lost circulation treating agents, inorganic lost circulation materials and temporary plugging additives, and compound plugging materials and additives with different particle sizes [2]-[5].

The drilling industry has suffered a lot because of lost circulation. In the United States and Canada, a well that has lost circulation will have a mud cost of anywhere from $\$ 8000$ to $\$ 50,000$ [6]. This is not including the rig costs because of the time lost, damage to the drill pipe and/or blowout.

Exploratory wells currently drilled by Petrobras in Brazil present average depths around $5500 \mathrm{~m}$ and in extreme situations can reach around $7000 \mathrm{~m}$. In this scenario, geological characteristics such as faults, natural fractures, high permeability zones and formations with vugular features are responsible for increased lost circulation events. Some exploratory wells present lost circulation events, increasing unproductive time and well construction costs. These loss events need to be combated and controlled to enable minimum well construction costs. The usual industry approach to addressing lost circulation events has been using flakes, granular and fibers materials such as graphite, calcium carbonates, mica, nut shells and swelling polymers [7]-[9].

From the four different loss formations, naturally fractured and drilling-induced fractured formations will be discussed because they are most commonly encountered while drilling.

Lost circulation can take place whenever there are favorable conditions that can help the drilling mud to propagate into the formations nearby. These conditions include:

1) The pore openings are larger than the mud particles.

2) Unconsolidated formations like porous sands and gravels can be fractured easily.

3) Vugular or cavernous formations provide channels for the loss to occur.

4) Circulating high-density drilling fluids induce fractures. Whenever the pipe is pushed down there are pressure surges which can cause lost circulation.

5) The presence of natural fractures makes it very easy for the drilling fluids to break down such formations [10].

The nature of losses as a result of lost circulation can be categorized in terms of degree and the time needed to control them. The two types of losses are:

1) Minor losses: These are losses in the range of 6 - 470 barrels that are stopped within 48 hours.

2) Major losses: These are losses greater than 470 barrels that take more than 48 hours to stop [11].

After lost circulation takes place, the level of mud in the annulus is reduced which causes the hydrostatic pressure in the annulus to fall below the pore pressure of the formation. As a result, the formation fluid enters into the well bore leading to a blowout. With no mud coming back to the surface, there are no cuttings that reveal the type of formation being drilled into. The productivity of the zone-bearing reserves is also decreased because of mud loss [12].

A common chemical lost circulation material is often expensive and the cost is higher, and conventional plugging materials cannot effectively plug the malignant leakage such as cave. Other countries studied the loss and loss circulation control mechanism during drilling earlier: the former Soviet Union developed the plugging agent series based on urea resin and phenol resin, and propylene polymers plugging agent series, and plugging agent slurry based on the latex [13]. In UK Brent oil field have developed a new type modified fiber material made up of fiberglass coated with surfactant and dispersant, which can resist high temperature of $232^{\circ} \mathrm{F}$, and solve the problems of lost circulation in that region [14]. Phillips Company developed a high filtration lost circulation material called DiasealM which can permeate into the formation and then filtrate quickly under the action of pressure difference, and solid-phase in the liquid gathered thicker and thicker, and formed filter cake, and then compacted the leakage channels [15]. M-I developed cross linking bridge series products such as PLUG FORM-A-PLUG [16]. Recent years there appeared hot-melt rubber plugging agent, expanded granular plugging agent, shear thickening fluid plugging agent, oil absorption solid material plugging agent, olefin plugging agent and absorbent polymer plugging agent and so on, and these agents can effectively solve the leakage problem of permeable formation and micro cracks formation, but they cannot solve the serious leakage such as natural fracture holes, holes or cave formation.

Varieties of methods have been developed in an attempt to deal with such a problem. One of the most commonly used methods is to place bridging materials into the leakage zone [17]-[23]. These materials act to bridge or seal the cracks, crevices, fissures, or other porous or faulty formations into where the drilling fluid is lost, thereby forming a barrier for preventing further loss of the drilling fluid. Such materials, however, have proved deficient in one or more respects. With rare exceptions, most of them are not effective in binding to each other or to the formations without actually forming an effective seal, thus they have a tendency to deteriorate under 
high pressure, and for the same reason lost circulation is likely to recur [24]-[28].

In addition to such particulate based treatments, cement may be another option to seal off the leakage zone. The cement slurry, commonly prepared by mixing cement powder with water, is forced into the problem formation and allowed to solidify therein. There are many factors that have been suggested to have a potential for the performance of the cement slurry.

The main idea of this study is to investigate and evaluate cement plug technology used in the oil industry with the aim of reducing and minimizing lost circulation event during drilling operations And finally, the application of a cement plug is studied in one well of the exploration Gas Field (National Iranian Oil Company) and the reasons of successful of this cement plug are examined.

\section{Preparation and Physical and Chemical Properties of the Novel Cement Plug}

\subsection{Preparation Procedures}

The raw materials, mainly bauxite, limestone and gypsum, were sintered at $1000^{\circ} \mathrm{C}-1400^{\circ} \mathrm{C}$ for a given period of time, and they were ground into powders with a required particle size and then mixed with cement slurry. The density of the slurry was $1.89 \mathrm{~g} / \mathrm{cm}^{3}$. The rheological property of the cement slurry was measured using a FANN model 35 type rotating viscosimeter.

The cement slurry composition and rheology properties are given in Table 1.

\subsection{Physical and Chemical Properties}

\subsubsection{Appearance Characteristics}

The raw materials are granular and relatively chemically inert at room temperature and dry conditions.

\subsubsection{Distribution of the Particle Sizes}

The distribution of the particle sizes was determined by screening $1 \mathrm{~kg}$ of the sample for $10 \mathrm{~min}$ using a screen.

\section{Experimental Work}

The mixture was packed into a glass tube, and then the tube was completely immersed in a water bath. It acts as hydrolysis reaction with water at various temperatures for varying periods of time to form cementing plug. At the completion of curing, the glass tube was broken gently to remove the cementing structure. Finally, the cementing body was grounded, dried in an oven at $30^{\circ} \mathrm{C}$ for $10 \mathrm{~h}$, and then reserved for use.

\section{The Effects of Temperature and Time on Cement Plug Compression Strength}

The cementing structure was formed at different temperatures $\left(30^{\circ} \mathrm{C}, 80^{\circ} \mathrm{C}\right.$, and $\left.120^{\circ} \mathrm{C}\right)$ for different periods of time ( 3 h, 9 h, 12 h, and 24 h), and the resulting compressive strength is shown in Table 2. N.M. represents that the compressive strength of the cementing body is too low to be measured, or that the self-binding agent fails to consolidate. Temperature and time have been shown to have a significant effect on the compressive strength of the cementing structure formed by the self-binding agent.

Specially, high temperature appears to be beneficial for the formation of the cementing structure. Also, time can also be a critical factor affecting the compressive strength of the cementing body, the longer the time, the

\section{Table 1. Cement slurry composition and rheology properties.}

\begin{tabular}{ccccc}
\hline & Cement slurry composition & \multicolumn{2}{c}{ Rheology properties of cement slurry } \\
\hline Cement & Sacks & 115 & rpm & Dial \\
Silica Flour & Lbs & 2280 & 600 & 150 \\
Fluid loss & Lbs & 460 & 300 & 91 \\
Retarder & 250 & 200 & 58 \\
Gas Block & Lbs & 20 & 100 & 24 \\
Deformer & Lbs & 35 & 6 & 8 \\
Fresh water & Lbs & 22 & 3 & 3 \\
\hline
\end{tabular}


Table 2. Compressive strength of the cementing plug formed at different temperatures for different periods of time (MPa).

\begin{tabular}{cccc}
\hline \multirow{2}{*}{ Time (h) } & & Temperature $\left({ }^{\circ} \mathbf{C}\right)$ & 120 \\
\cline { 2 - 4 } & 30 & 80 & N.M. \\
9 & N.M. & N.M. & 2.91 \\
12 & N.M. & N.M. & 3.42 \\
24 & N.M. & 2.96 & 5.62 \\
\hline
\end{tabular}

better the compressive strength of the cementing structure.

\section{Field Results}

The cement plug has been applied on well to date (January 2013) in Iran, where attempts to cure losses with other materials such as LCM pill were not successful as well.

\section{Case Study}

The operator wanted to stop losses in a severely depleted zone (Dalan. A) at 12,000 ft so that the lower productive zone could be evaluated. Conventional LCM pill including $15 \mathrm{ppb}$ of mica sized fine, $10 \mathrm{ppb}$ mica sized medium, and $15 \mathrm{ppb}$ of fiber LCM with regard to nozzle size of bit had been spotted. A 11.2-ppg mud density was required to control the pressure in the Dalan. A lime stone.

After drilling, losing complete returns. So, cement plug was pumped through drill pipe. The pipe was quickly pulled to the surface before waiting on cement.

When the drill string runs back to the top of the cement plug at 11,600 $\mathrm{ft}$ (the intermediate casing shoe), the mud circulation started. After a few minutes, Mud return flow was observed. After drilling the cement plug, the rig pumps were shut down and flow and lost circulation (flow check) were monitored for the next one hour. During one hour, no flow and lost circulation were observed. The operator was able to drill through the cement plug and on to original bit depth of 12,100 ft. Drilling resumed past 12,100 ft with no further losses.

\section{Conclusions}

The following conclusions can be derived from the study:

1) The cementing structure formed by the cement plug has high stability and with the increase of storing time its compressive strength changes little.

2) Field case histories indicate that drilling mud losses associated with severely depleted lime stone can be reduced with the use of a newly developed cement plug.

\section{Acknowledgements}

The author would like to thank N.I.O.C for allowing this work to be published. Special thanks to Eng. Farhad Ekramnia, Mr. heidar ghanbarzadeh and Mr. bahman pirmoradian for valuable discussion and input.

\section{References}

[1] Kharrat, R. (2000) Drilling Fluids Lecture Notes. Petroleum University of Technology, Ahwaz.

[2] Fuh, G.F., et al. (1992) A New Approach to Preventing Lost Circulation. SPE 24599 SPE Annual Technical Conference and Exhibition, Washington DC.

[3] Bannerman, M. and Chevron, J. (2005) New API Practices for Isolating Potential Flow Zones During Drilling and Cementing Operations. SPE Annual Technical Conference and Exhibition, Society of Petroleum Engineers, Texas. http://dx.doi.org/10.2118/97168-MS

[4] Amanullah, M.D. (2006) Experimental Evaluation of Formation-Strengthening Potential of a Novel Gel System. IADC/SPE Asia Pacific Drilling Technology Conference and Exhibition, Society of Petroleum Engineers, Bangkok.

[5] Hong-feng, G., Zhen-shan, B. and Chang-qing, Q. (2000) Research on Bridge Plugging Technology and Blocking Agents. Petroleum Drilling Technology, 5, 39-40. 
[6] Hong-li, Z., Yan, G. and Zhi-long, W. (2004) Lost Circulation Materials in China. Special Oil Gas Reservoir, 2, 1-2.

[7] Bugbee, J.M. (1953) Lost Circulation-A Major Problem in Exploration and Development. Spring Meeting of Southwestern District, Division of Production, Texas.

[8] Waldmann, A.T.A., Martins, A.L., Aragão, A.F.L. and Lomba, R.F.T. (2005) Predicting and Monitoring Fluid Invasion in Exploratory Drilling. Journal of SPE Drilling \& Completion, 20, 268-275.

[9] Castro, J., Solis, L., Urdaneta, J.A. and Morales, J.V.A. (2011) First Application of Heat-Activated, Rigid Rapid-Fluid System in Deepwater Environment in Mexico Helps to Cure Severe Loss of Circulation: A Case History. SPE/IADC Drilling Conference and Exhibition, Amsterdam, 1-3 March 2011.

[10] Chilingar, G.V. and Vorabutr, P. (1981) Drilling and Drilling Fluids.

[11] Canson, B.E. (1985) Lost Circulation Treatments for Naturally Fractured, Vugular, or Cavernous Formations. SPE/ IADC 13440.

[12] Chilingar, G.V. and Vorabutr, P. (1981) Drilling and Drilling Fluids.

[13] Zhang, X.W., Li, S. and Zhang, J., Sun, J.S. and Yang, Z. (2009) Research Progress on Lost Circulation Materials and Lost Circulation Control Technology. Drill Fluid and Completion Fluid, 6, 74-76.

[14] Zhao, X.H. and Wang, F.C. (2004) Research Development of Waste Drilling Fluids Disposal. Drilling Fluid \& Completion Fluid, 2, 45-50.

[15] Marriott, T. and Griffith, J. (2005) Foamed Conventional Lightweight Cement Slurry for Ultralow Density and Low Ecds Solves Lost-Circulation Problem across Coal Formations: A Case History. SPE Annual Technical Conference and Exhibition, 9-12 October 2005, Society of Petroleum Engineers, Texas. http://dx.doi.org/10.2118/96108-MS

[16] Bruton, J.R., Ivan, C.D. and Heinz, T.J. (2001) Lost Circulation Control: Evolving Techniques and Strategies to Reduce Downhole Mud Losses. SPE/IADC Drilling Conference, Society of Petroleum Engineers, Amsterdam. http://dx.doi.org/10.2118/67735-MS

[17] Wang, Z.M., Qiu, Z.S., Xu, J.F. and Huang, W.A. (2007) Balance Area of Compound Lost Circulation Control and Its Application in Novel Lost Circulation Simulator. Acta Petrologica Sinica, 28,143-145.

[18] Xu, T.T., Liu, Y.J. and Shen, W. (1997) Technology of Lost Circulation Resistance and Control during Drilling Engineering. Petroleum Industry Press, Beijing, 217-220.

[19] Wu, B., Yan, J.N. and Zou, S.L. (2002) Formation Damage Control Technology for Fractured Reservoir in TARIN Oilfield. Journal of the University of Petroleum, 26, 32-34.

[20] Zhang, D.J. (2000) Application of Lost Circulation Prevention and Control Technology for Super High Pressure Yangdu-3 Well. Natural Gas Industry, 20, 33-36.

[21] Yan, J.N., Ed. (2001) Drilling Fluid Technology. The Press of University of Petroleum, Dongying, 358-359.

[22] Gelan, E.L. and David, A.G. (1990) Design and Evaluation of Lost-Circulation Materials for Severe Environments. Journal of Petroleum Technology, 44, 328-337.

[23] Huang, L.X. and Zhang, G.M. (1999) Mechanism of Pore Throat’s Plugging Due to Solid Particles in a Formation. Journal of Jianghan Petroleum Institute, 21, 41-43.

[24] Labenski, F., Reid, P. and Stantos, H., Eds. (2003) Drilling Fluids Approaches for Control of Wellbore Instability in Fractured Formations. SPE/IADC Middle East Drilling Technology Conference and Exhibition, SPE 85304, Abu Dhabi, 134-145. http://dx.doi.org/10.2118/85304-ms

[25] Cui, Y.-C. and Zhang, Y. (2000) Application of Fractal Theometry Theory to Optimal Selection of Temporary Plugging Agents. Journal of the University of Petroleum, 24, 17-20.

[26] Zeng, M.Y., Shi, X.B. and Wei, M.J. (2006) Application of Drilling Fluid Shielding and Temporary Block Technology in SHIZIGOU Oilfield. Journal of Southwestern Petroleum Institute, 28, 67-70.

[27] Liu, A.-J. (2003) Study on the New Techniques of Superior Shielding and Temporary Plugging Drill-in Fluids. Journal of Shandong Institute of Building Material, 17, 83-86.

[28] Alberty, M. and McLean, M. (2004) A Physical Model for Stress Cages. SPE Annual Technical Conference and Exhibition, Houston. http://dx.doi.org/10.2118/90493-ms 